\title{
Survey Information
}

Survey location:

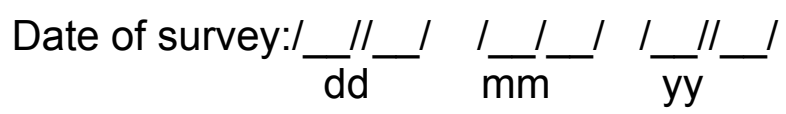

Interviewer ID /__ _ I _ I _ Initial of interviewer + initials of primary care health center)

Time of the interview: I_I__ I I I I I Hour Minute

Participant ID Number / $/ / L / / \ldots$

Consent has been read: $I \ldots$ yes $I /$ no

$$
\text { If NO, END }
$$

Consent has been obtained, orally or written form: /__ yes

I_ I non

\section{Additional Information that may be helpful}

\section{Contact phone number where possible}

The information collected through this document will be treated with the utmost confidentiality and will be subject to the rules of ethics relating to the respect of patient privacy and medical confidentiality.

\section{Demographic Information}

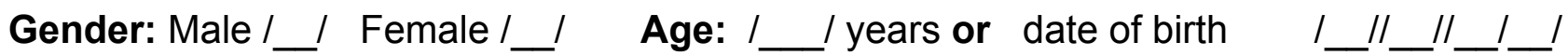

Residence Area: Urban /_ / Rural /_ I

Marital status: single I_ / married /__ divorced /__ widowed I_ I

Education: Can read and write / _ c cannot read nor write I__ I

Level of education: illiterate I_ / primary I_ I secondary I_ I university I_ I

Occupation: without /_ I with /__ if with, specify:

Monthly income per household in Dhs: $\square \leq 1500 \square>1500-\leq 2000 \square>2000-3000 \square>3000-4999$ $\square \geq 5.000$

Health insurance coverage: Private insurance I_ / RAMED / _ without / I

\section{Risk factors}

Blood pressure duration: years

\section{Circumstance of discovery of high blood pressure}

Accidental $\square$ Routine exam $\square$ Systematic exam $\square$ Complication $\square$ Associated disease $\square$ Other, to specify: 
General knowledge about blood pressure

To be completed at the end

\section{Symptoms}

Headache

Auditory whistling

Blurred vision (feeling of flies in

front of the eyes)

Dizziness

Palpitation (fast heart rate)

Difficulty breathing

Epistaxis (bleeding nose)

Hematuria (presence of blood in the urine)

OEdema

\section{Complications}

Stroke

Heart attack

Kidney damage

Eye damage

Compliance with preventive guidelines

Dietary and hygiene rules

- loss of weight

- $\downarrow$ consumption of alcohol

- $\downarrow$ Tobacco

Physical activity

Stress avoidance

Dietary compliance

Compliance with treatment

Taking medication that can lead to an increase in hypertension Self-measurement of blood pressure and regular medical (monitoring) follow-up

Variables associated with lifestyle / behaviors

-Tobacco

If yes, specify : $\bigcirc$ current smoker $\bigcirc$ former smoker How many years have you stopped smoking?:

Number of cigarettes per day: 


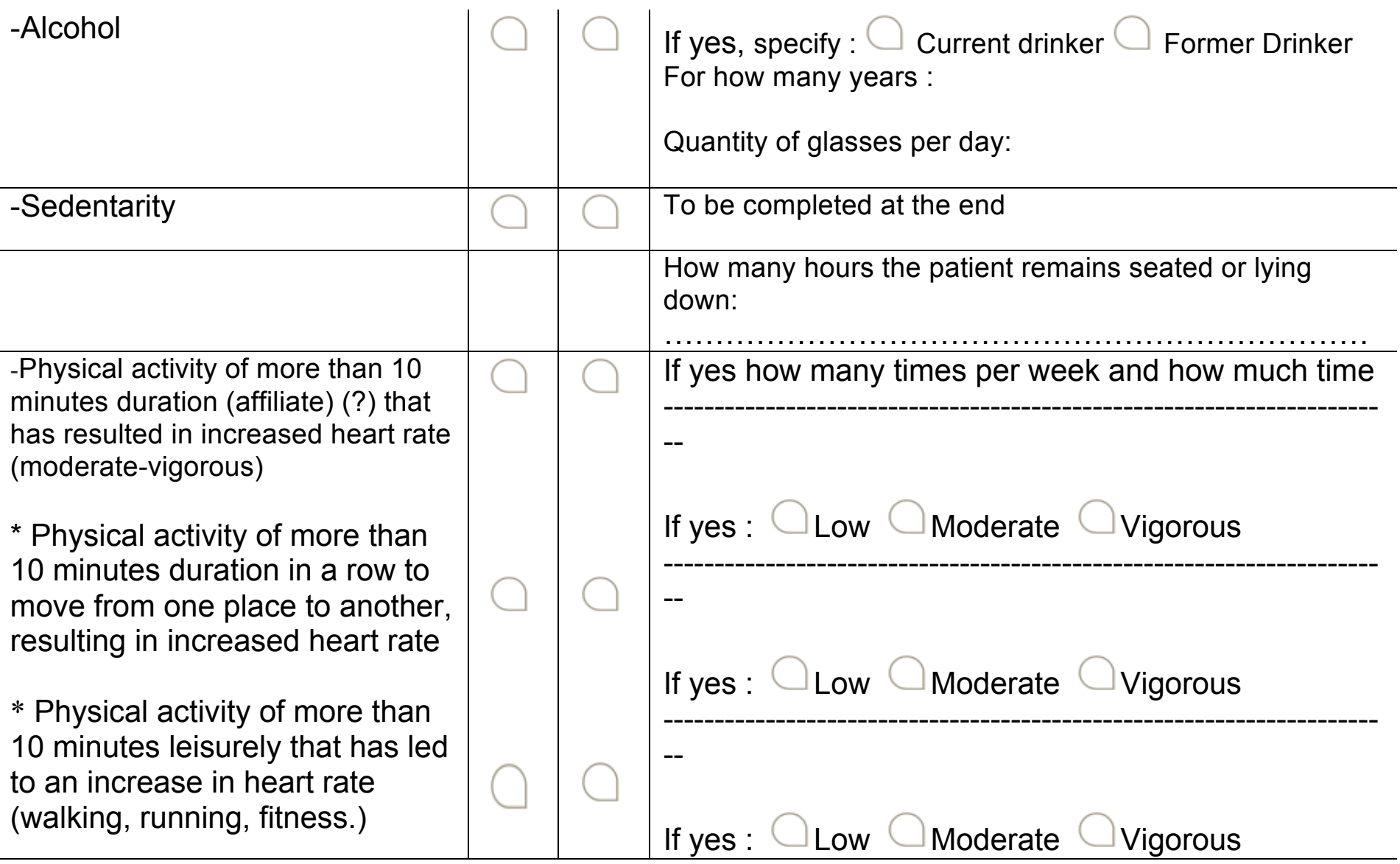

NB: low refers to intensity if the activity is carried out only one day or during less than 2 hours a week, while intense if it will be carried out at least for 4 days / week or more than 7 hours / week. it will be called moderate for the rest

\begin{tabular}{|c|c|c|c|}
\hline Stress & & & $\bigcirc$ no $\bigcirc$ Moderately $\bigcirc$ a lot \\
\hline Dietary compliance & yes & no & To be completed at the end \\
\hline -Consumption of salt & & & If yes : $\bigcirc$ semi salty $\bigcirc$ salty \\
\hline -Difficulty to follow the diet & & & Why? If yes, please explain : \\
\hline $\begin{array}{l}\text { Family history of blood } \\
\text { pressure }\end{array}$ & & & $\begin{array}{l}\text { If yes : } \bigcirc \text { mother } \bigcirc \text { father } \bigcirc \text { sister } \bigcirc \text { brother } \bigcirc \\
\text { grandparent }\end{array}$ \\
\hline Comorbidity & yes & no & \\
\hline -Heart disease & & & 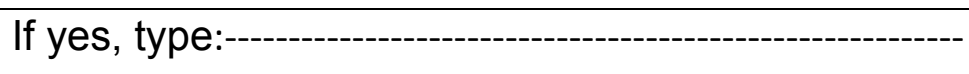 \\
\hline -Diabetes & & & If yes type : $\bigcirc$ type 1 \\
\hline -Dyslipidemia & & & \\
\hline -Chronic renal failure & O & 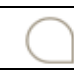 & \\
\hline Treatment & yes & no & Name of the drug \\
\hline
\end{tabular}




\begin{tabular}{|c|c|c|c|}
\hline $\begin{array}{l}\text { (Pharmaceutical Trade Mark) } \\
\text { drug } \\
\text { - Monotherapy }\end{array}$ & $\bigcirc$ & $C$ & $\begin{array}{l}\bigcirc \text { Angiotensin II converting enzyme inhibitor } \bigcirc \\
\text { thiazide diuretic } \bigcirc \text { beta-blocker } \bigcirc \text { calcium channel } \\
\text { blocker } \bigcirc \text { Angiotensin II receptor antagonist }\end{array}$ \\
\hline -Dual therapy & $\bigcirc$ & $\bigcirc$ & $\begin{array}{l}\bigcirc \text { Angiotensin II converting enzyme inhibitor } \bigcirc \\
\text { thiazide diuretic } \bigcirc \text { beta-blocker } \bigcirc \text { calcium channel } \\
\text { blocker } \bigcirc \text { Angiotensin II receptor antagonist }\end{array}$ \\
\hline -triple therapy & $\bigcirc$ & $\bigcirc$ & $\begin{array}{l}\bigcirc \text { Angiotensin II converting enzyme inhibitor } \bigcirc \\
\text { thiazide diuretic } \bigcirc \text { beta-blocker } \bigcirc \text { calcium channel } \\
\text { blocker } \bigcirc \text { Angiotensin II receptor antagonist }\end{array}$ \\
\hline Generic drug (?) & $\bigcirc$ & $\bigcirc$ & $\begin{array}{l}\bigcirc \text { Angiotensin II converting enzyme inhibitor } \bigcirc \\
\text { thiazide diuretic } \bigcirc \text { beta-blocker } \bigcirc \text { calcium channel } \\
\text { blocker } \bigcirc \text { Angiotensin II receptor antagonist }\end{array}$ \\
\hline
\end{tabular}

Treatment time in months :

Compliance with treatment

To be completed at the end

Did you forget to take your medication this morning?

Have you been out of medication since the last consultation?

Have you had to take your treatment late compared to the usual time?

Have you ever missed your treatment because some days because of your memory lacking

Have you ever missed treatment because some days you feel that your treatment is doing more harm than good

Do you think you have too many (tablets) pills to take?

Frequency of blood pressure self-monitoring

Do you measure your home blood pressure?

\begin{tabular}{|c|c|}
\hline & To be completed at the end \\
\hline & $\bigcirc$ yes $\bigcirc$ no \\
\hline ? & $\begin{array}{l}\bigcirc \text { yes } \bigcirc \text { no. If yes : Did you: } \\
\text { buy it from the pharmacy } \\
\text { take another drug } \\
\text { remained without } \bigcirc \text { other }\end{array}$ \\
\hline usual & $\bigcirc_{\text {yes }} \bigcirc$ no \\
\hline because & $\bigcirc_{\text {yes }} \bigcirc$ no \\
\hline eel that & $\bigcirc_{\text {yes }} \bigcirc$ no \\
\hline & $\bigcirc$ yes $\bigcirc$ no \\
\hline no & To be completed at the end \\
\hline no & $\begin{array}{l}\text { If no, why: } \\
\text { No instrument of measure } \\
\text { other to specify }\end{array}$ \\
\hline
\end{tabular}

\section{Relationship with the care system}

\begin{tabular}{l|l|l}
$\begin{array}{l}\text { Do you go to(get an appointment with) a doctor } \\
\text { for your tension }\end{array}$ & $\bigcirc$ yes $\bigcirc$ no & $\begin{array}{l}\text { If yes, does it belong to the } \\
\text { sector } \bigcirc \text { public } \bigcirc \text { private }\end{array}$ \\
\hline Frequency of medical appointments & $\begin{array}{l}\bigcirc \text { once a month } \bigcirc \text { every } 2 \text { months } \bigcirc \\
\text { every three months } \bigcirc \text { every six months } \\
\text { never } \bigcirc \text { just if I fell myself bad }\end{array}$ \\
\hline What is the distance between your house and & $\bigcirc<6 \mathrm{~km} \bigcirc$ between 6 and $10 \mathrm{~km} \bigcirc>10$
\end{tabular}


health center

$\mathrm{km}$

Time taken to reach the health center

less than $30 \mathrm{~min}$

between $30 \mathrm{mn}$ and $1 \mathrm{~h}$

transportation mode

more than one hour walk $\bigcirc$ chariot $\bigcirc$ Taxi $\bigcirc$ Bus $\bigcirc$ car bicycle

Availability of the drug for blood pressure

Patient doctor relationship yes no

How long does the doctor allow you during the medical appointment (consultation) in term of time (in minutes)

Do you discuss with your doctor your personal concerns/issues about hypertension?

Do you (feel the desire of) expect your doctor to better understand you?

Are you setting blood pressure goals?

Do someone (we) call you when you miss your appointment

Do you have an association for hypertensive

Anthropological measurement (?)

\begin{tabular}{|l|l|l|}
\hline & Systolic, in $\mathrm{mmHg}$ & Diastolic, in $\mathrm{mmHg}$ \\
\hline $1^{\text {th }}$ measure, right arm & & \\
\hline $1^{\text {st }}$ measure, left arm & & \\
\hline $\begin{array}{l}2^{\text {nd }} \text { measurement at the high pressure } \\
\text { arm }\end{array}$ & & \\
\hline $\begin{array}{l}3^{\text {rd }} \text { measurement at the high pressure } \\
\text { arm }\end{array}$ & & \\
\hline Mean & & \\
\hline
\end{tabular}

Weight (kg):

Hip circumference (cm):

Height (cm):

Waist $(\mathrm{cm})$ :

Blood pressure during last three visits $(\mathrm{mmHg})$ :

Follow-up review

ECG: $\bigcirc$ yes no Result:

Electrolytes or ions (sodium, potassium): $\square$ yes

Creatinine blood test:

no Result:

no Result:

Fasting blood glucose or glycated Hemoglobin (HbA1c): $\bigcirc$ yes $\bigcirc$ no Result:

Lipid profil:

Total Cholesterol:

C-HDL:

C-LDL:

Triglycerides:

$\begin{array}{lll}\text { yes } & \bigcirc \text { no } & \\ \text { yes } & \bigcirc \text { no } & \text { Result: } \\ \text { yes } & \text { no } & \text { Result: } \\ \text { yes } & \bigcirc \text { no } & \text { Result: } \\ \text { yes } & \bigcirc \text { no } & \text { Result: }\end{array}$




\section{Doctor's questionnaire on blood pressure}

Survey information

Survey location:

Patient identify

I_II_I I
Date of survey:/

$-\frac{I}{\mathrm{dd}}+\frac{1}{\mathrm{~mm}}-1 / \frac{1}{\mathrm{yy}}$

(patient order number + interviewer ID)
Weight (kg) :

Hip circumference (cm) :

Blood pressure during last visit $(\mathrm{mmHg})$ :
(Size) Height (cm) :

Waist (cm):

The information collected by means of this document will be treated with the utmost confidentiality and are subject to the rules of ethics relating to the respect of the medical confidentiality.

Treatment modification

Management of associated cardiovascular risk factors: (Nicotine) Replacement therapy for weaning tobacco $\square$, Weight loss $\square$, control of diabetes $\square$, taking a statin $\square$, taking a cardioaspirin $\square$

\section{Please check (tick) all the corresponding box that apply}

\begin{tabular}{|l|l|}
\hline Modified treatment & Check box \\
\hline Blood pressure in poorly controlled consultation & \\
\hline Self-measurement made by poorly controlled patient & \\
\hline Poorly tolerated treatment & \\
\hline Prescription of generic drugs & \\
\hline Trial of a new drug & \\
\hline Prescription of a fixed combination & \\
\hline Simplification of the medical prescription & \\
\hline Decrease in the cost of prescription & \\
\hline Follow-up of Ministry of Health program guidelines & \\
\hline Other(s) to be specified & \\
\hline
\end{tabular}




\begin{tabular}{|l|l|}
\hline Unmodified treatment & Check box \\
\hline Poor compliance with treatment by the patient & \\
\hline Controlled blood pressure at the previous visit & \\
\hline Reluctance of the patient to take a new medicine & \\
\hline Cost of important drugs & \\
\hline White coat hypertension syndrome & \\
\hline Etiological blood test in progress & \\
\hline $\begin{array}{l}\text { Difficulty in controlling blood pressure despite several } \\
\text { therapeutic modifications }\end{array}$ & \\
\hline Recent change of treatment (less to 4 weeks) & \\
\hline Multiple drug intolerance syndrome & \\
\hline $\begin{array}{l}\text { Current intake of drugs that can affect the BP (anti } \\
\text { inflammatory, corticoids, estrogen-progestative association ...) }\end{array}$ & \\
\hline $\begin{array}{l}\text { Management of associated cardiovascular risk factors } \\
\text { (smoking cessation, weight loss, diabetes balance, statin) }\end{array}$ & \\
\hline Chronic alcoholic poisoning & \\
\hline Lack of time in consultation to explain the new treatment & \\
\hline Lack of motivation for the patient & \\
\hline Recent emotional event & \\
\hline Others & \\
\hline
\end{tabular}

